\title{
UPAYA MENINGKATKAN PEMAHAMAN KONSEP MATEMATIS SISWA KELAS 2 SDN 133 PEKANBARU MELALUI PENERAPAN MODEL PEMBELAJARAN LANGSUNG (DIRECT LEARNING)
}

\author{
Muslina \\ SDN 133 Pekanbaru, Jl. Ikhlas II No.17, Tangkerang Tim, Pekanbaru, Riau, 28131 \\ Email penulis: muslinasdn133@gmail.com
}

\begin{abstract}
Students Mathematic Concept Comprehension is one of the basic abilities that students must possess. The problem found by researchers from the symptoms observed by the researcher is the lack of ability of students' mathematical understanding in the distribution material. The study aims to improve understanding of students' mathematical concepts through Direct Learning models. This type of research is Classroom Action Research (CAR) with data analysis techniques using qualitative and quantitative descriptive approaches. The subject of this research was elementary school students of grade 2 SDN 133 Pekanbaru. The results of this study that there was an increase in learning outcomes starting from the pre-action stage to the second cycle with a classical increase in the second cycle was $83.33 \%$ which was completed in the understanding of mathematics concepts test.
\end{abstract}

Keywords: Mathematic Concept Comprehension, Direct Learning Model

\begin{abstract}
Abstrak
Kemampuan pemahaman konsep merupakan salah satu kemampuan dasar yang mesti dimiliki oleh siswa. Masalah yang ditemukan oleh peneliti dari gejala-gejalah yang diamati peneliti adalah masih kurangnya kemampuan pemahaman matematis siswa dalam materi pembagian. Penelitian bertujuan untuk meningkatkan pemahaman konsep matematis siswa melalui model Pembelajaran Langsung (Direct Learning). Jenis Penelitian yang dilakukan adalah Penelitian Tindakan Kelas (PTK) dengan teknik analisis data menggunakan pendekatan kualitatif dan deskriptif kuantitatif. Subjek penelitian ini siswa SD kelas 2 SDN 133 Pekanbaru Hasil dari penelitian ini bahwa terjadi peningkatan hasil belajar mulai dari tahap pra tindakan sampai ke siklus 2 dengan peningkatan secara klasikal pada siklus kedua adalah $83.33 \%$ yang tuntas dalam tes pemahaman kosep matematika.
\end{abstract}

Kata kunci: Pemahaman Konsep Matematis, Model Pembelajaran Langsung

\section{PENDAHULUAN}

Memahami suatu konsep dalam matematika menjadi dasar untuk siswa dapat menyenangi matematika. Pentingnya pemahaman konsep dalam matematika karena matematika mempelajari konsep-konsep yang saling terhubung dan saling berkesinambungan. Oleh sebab itu kemampuan memahami suatu konsep sangat dibutuhkan oleh siswa dalam pelajaran matematika.

Matematika itu sendiri adalah ilmu pasti yang harus di telaah kebenarannya dan tidak bisa disamakan dengan ilmu pengetahuan lain yang cukup dengan membaca dan menghafal kita bisa mengerti. Pelajaran matematika disekolah dianggap oleh sebagian besar siswa sebagai sesuatu yang abstrak dalam praktek pembelajaran. Apabila guru masih menggunakan paradigma lama dalam mengajar yaitu guru lebih mendominasi proses pembelajaran dimana pembelajaran yang dilaksanakan masih menggunakan metode ceramah dengan peserta didik hanya datang, duduk, mendengarkan, mencatat materi setelah itu pulang. Oleh karena itu pembelajaran yang dahulunya berpusat pada guru 
diganti dengan pembelajaran yang berpusat pada siswa dengan tujuan membuat siswa lebih aktif dalam proses belajar mengajar.

Pembelajaran matematika identik sebagai mata pelajaran rumit yang membosankan. Hal ini tentu saja banyak pelajar yang menghindari untuk belajar mata pelajaran tersebut. Disinilah peran orang tua dan guru bagaimana membuat pelajaran matematika jadi topik menarik dan menyenangkan. Ada beberapa cara agar anak bisa belajar secara menarik dan menyenangkan antara lain: pertama, menciptakan suasana belajar matematika dengan suasana santai, nyaman dan interaktif. Dengan munculnya perasaan nyaman dan interaktif akan dapat memunculkan rasa percaya anak pada dirinya bahwa matematika itu tidak sulit. Tumbuhkan motivasi belajar pada diri pelajar, dengan adanya motivasi yang jelas, matematika menjadi pelajaran yang disukai tanpa terbebani. Kedua berkomunikasilah dengan mereka tentang sesuatu yang menyenangkan sesuai dengan minatnya, dengan seperti ini otak mereka akan berpikir dan mencari hal-hal yang mereka sayangi

Pentingnya pemahaman konsep dalam matematika itu tertuang di dalam Standar Nasional yang dikeluarkan BNSP. Salah satu kemampuan yang harus dimiliki oleh siswa Menurut BNSP (2006) adalah agar siswa memiliki kemampuan dalam hal Memahami konsep matematis, serta menjelaskan keterkaitan antar konsep dan menggunkan konsep tersebut dalam menyelesaikan soal atau masalah. karena matematika mempelajari konsep-konsep yang saling terhubung dan saling berkesinambungan. Matematika adalah ilmu pasti yang harus di telaah kebenarannya dan tidak bisa disamakan dengan ilmu pengetahuan lain yang cukup dengan membaca dan menghafal kita bisa mengerti. Perlunya mengetahui dan memahami permasalahan pada sebuah soal matematika adalah hal yang akan memudahkan seseorang untuk memilih solusi penyelesaian yang tepat.

Pada faktanya yang ditemukan guru, bahwa pemahaman konsep yang dimiliki siswa dalam memahami materi pembagian masih kurang. Hal ini dapat dilihat dari hasil ulangan yang diberikan guru menunjukkan masih banyaknya siswa yang nilai ulangannya masih dibawah KKM. KKM yang ditetapkan sekolah adalah 70. Fakta lainnya dapat dilihat dari gejala-gejala yang ditemukan guru:

1. Sedikit sekali siswa yang bisa menjawab ketika guru meminta siswa untuk memberikan contoh dari konsep-konsep pembagian yang telah dipelajari.

2. Jika diberikan soal yang berbeda dari contoh, masih ada siswa yang tidak dapat menyelesaikannya.

3. Masih ada siswa yang belum paham dengan persoalan yang ada pada soal.

4. Siswa terlihat kesulitan untuk memahami materi ajar baru. Hal ini karena sebagian besar siswa tidak ingat konsep-konsep dasar untuk materi yang sedang dipelajari.

5. Sebagian besar siswa hanya menghafal rumus yang diberikan bukan memahaminya.

Berdasarkan gejala-gejala yang telah diungkapkan, maka perlu dicarikan solusi untuk mengatasi permasalahan tersebut. Salah satu upaya yang bisa dilakukan guru adalah dengan menerapkan sebuah Model dalam mengatasi permasalahan itu yaitu model Pembelajaran Langsung ( Direct Learning).

Model Pembelajaran Langsung menurut Paul Eggen dan Don Kauchak (Satrio Wahono:2012) adalah suatu model yang menggunakan peragaan dan penjelasan guru digabungkan dengan latihan dan umpan balik siswa untuk membantu mereka mendapatkan pengetahuan dan keterampilan nyata yang dibutuhkan untuk pembelajaran lebih jauh.

Para pakar teori belajar menggolongkan pengetahuan menjadi dua macam, yaitu pengetahuan deklaratif dan pengetahuan prosedural. Pengetahuan prosedural yaitu pengetahuan mengenai bagaimana orang melakukan sesuatu. Misalnya, bagaimana melakukan operasi matematika. 
Model pembelajaran langsung dirancang secara khusus untuk menunjang proses belajar siswa berkenaan dengan pengetahuan prosedural dan pengetahuan deklaratif yang terstruktur dengan baik dan dapat dipelajari selangkah demi selangkah. Pembelajaran langsung tidak sama dengan metode ceramah, tetapi dan resitasi (mengecek pemahaman dengan tanya jawab) berhubungan erat dengan model pembelajaran langsung.

Pembelajaran langsung memerlukan perencanaan dan pelaksanaan yang cukup rinci terutama pada analisisi tugas. Pembelajaran langsung berpusat pada guru, tetapi tetap harus menjamin terjadinya keterlibatan siswa. Jadi lingkungannya harus diciptakan yang berorientasi pada tugas-tugas yang diberikan kepada siswa.

Menurut Slavin (Melvin L. Silberman: 2006), tahapan dari pembelajara langsung adalah sebagai berikut;Menginformasikan tujuan pembelajaran dan orientasi pelajaran kepada siswa. Dalam tahap ini guru menginformasikan hal-hal yang harus dipelajari dan kinerja siswa yang diharapkan; Me-review pengetahuan dan keterampilan prasyarat. Dalam tahap ini guru mengajukan pertanyaan untuk mengungkap pengetahuan dan keterampilan yang telah dikuasai siswa; Menyampaikan materi pelajaran. Dalam fase ini, guru menyampaikan materi, menyajikan informasi, memberikan contohcontoh, mendemontrasikan konsep dan sebagainya; Melaksanakan bimbingan. Bimbingan dilakukan dengan mengajukan pertanyaan-pertanyaan untuk menilai tingkat pemahaman siswa dan mengoreksi kesalahan konsep;Memberikan kesempatan kepada siswa untuk berlatih. Dalam tahap ini, guru memberikan kesempatan kepada siswa untuk melatih keterampilannya atau menggunakan informasi baru secara individu atau kelompok; Menilai kinerja siswa dan memberikan umpan balik. Guru memberikan reviu terhadap hal-hal yang telah dilakukan siswa, memberikan umpan balik terhadap respon siswa yang benar dan mengulang keterampilan jika diperlukan; Memberikan latihan mandiri. Dalam tahap ini, guru dapat memberikan tugas-tugas mandiri kepada siswa untuk meningkatkan pemahamannya terhadap materi yang telah mereka pelajari.

Berdasarkan Latar belakang yang telah diungkapkan maka peneliti akan melakukan Penelitian Tindakan Kelas dengan tujuan mengetahui "Bagaimana penerapan Model pembelajaran langsung dalam meningkatkan pemahaman konsep pada materi pembagian siswa kelas 2 Sekolah Dasar Negeri 133 Pekanbaru?"

\section{METODE}

Jenis penelitian yang digunakan peneliti adalah Penelitian Tindakan Kelas (PTK). Menurut Arikunto (2006:96) PTK merupakan penelitian yang diterapkan guru kelas tempat dia mengajar dengan penekanan pada penyempurnaan atau peningkatan proses dan praktis pembelajaran. Penelitian ini menggunakan pendekatan kualitatif dan deskriptif kuatitatif. Pendekatan kualitatif dalam penelitian ini saat mengamati proses proses pembelajaran dengan menggunakan Model Pembelajaran Langsung (Direct Learning), sedangkan statistif deskriptif kuantitatif digunakan untuk data berupa mean, standar deviasi, nilai maksimum, nilai minimum dan diagram-diagram yang digunakan. Penelitian ini menggunakan model Kemmis dan Mc.Tagart yaitu model skema yang menggunakan prosedur yaitu siklus spiral yang terdiri dari perencanaan, tindakan, obsevasi, dan refleksi. Penelitian ini sudah dilaksanakan dalam 2 siklus, dengan masing-masing siklus ada 2 kali pertemuan, serta $\mathrm{d}$ akhir setiap siklus di adakan tes untuk mengukur peningkatan pemahaman konsep siswa. Tidakan pendahuan peneliti dalam penelitian ini adalah dengan memberikan tes kepada sisw dan menganalisis secara klasikal hasil tes tadi.

Subjek peneltian ini adalah seluruh siswa kelas 2 SDN 133 Pekanbaru yang berjumlah jumlah 30 orang siswa. Siswa tersebut 19 orang laki -laki dan 11 orang perempuan dengan pokok bahasan pembagian bilangan.

Analisis ketuntasan hasil belajar siswa setelah menerapkan Model Pembelajaran Langsung dapat dilakukan dengan membagi jumlah siswa yang tuntas belajar dengan jumlah siswa secara 
keseluruhan. Kriteria ketuntsan siswa kelas II SDN 133 Pekanbaru dapat dikatakan meningkat jika: (1) Ketuntusan perorangan, seorang siswa dikatakan tuntas jika mencapai nilai $\geq 75$ dari nilai ideal 100 dengan rumus:

Nilai Siswa $=\frac{\sum \text { skor yang diperoleh }}{\sum \text { skor yang maksimal }} \times 100 \%$

(2)ketuntasan secara klasikal, suatu kelas dikatakan tuntas jika terdapat minimal 75\% yang memperoleh nilai $\geq 75$ dari maksimal $100 \%$ degan rumus:

$$
\text { Tingkat Ketuntasan secara klasikal }=\frac{\text { Jumlah siswa yg tuntas }}{\text { jumlah total siswa }} \times 100 \%
$$

\section{HASIL DAN PEMBAHASAN}

Analisis data deskriptif kuantitatif data penelitian mulai dari pra tindakan, siklus 1, dan siklus 2 disajikan dalam tabel 1.1 berikut:

\section{Tabel 1.1 Data Hasil Belajar siswa secara klasikal}

\begin{tabular}{lllll}
\hline No & $\begin{array}{l}\text { Hasil Belajar yang } \\
\text { Tuntas }\end{array}$ & Pra tindakan & Siklus 1 & Siklus 2 \\
\hline $\mathbf{1}$ & $\begin{array}{l}\text { Ketuntasan } \geq 75 \text { dari } \\
\text { nilai maksimal t100 }\end{array}$ & $63.33 \%$ & $73,33 \%$ & $83.33 \%$ \\
$\mathbf{2}$ & $\begin{array}{l}\text { Tidak memenuhi } \\
\text { KKM }(<75)\end{array}$ & $26.67 \%$ & $16.67 \%$ \\
Total & $100 \%$ & $100 \%$ & $100 \%$ \\
\hline
\end{tabular}

Berikut ditampilkan pula dalam bentuk diagram batang peningkatan Pemahaman Konsep matematika siswa pada pra tindakan, siklus 1 dan siklus ke 2 ketika sudah diterapkan model Pembelajaran Langsung (Direct Learning) terlihat pada gambar 1.1:

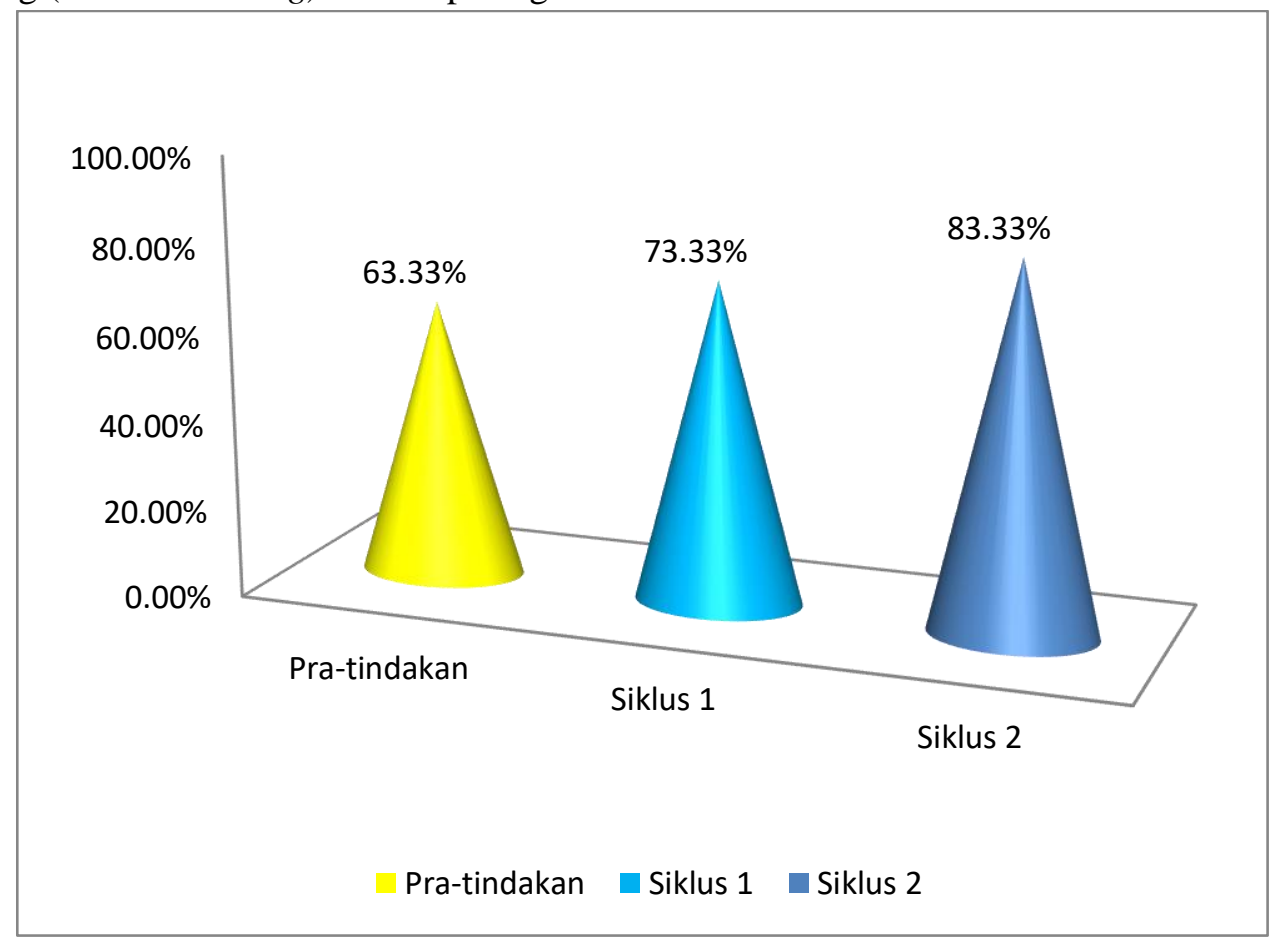

Gambar 1.1. Diagram Batang peningkatan Hasil Belajar Siswa 
Dari tabel 1.1 dan gambar 1.1 terlihat bahwa ketuntasan siswa secara klasikal mulai dari pra tindakan sampai ke siklus ke 2 mengalami peningkatan. Hasil belajar siswa yang tergolong dalam kategori tuntas pada tes pendahuan hanya sekitar $63,3 \%$ yaitu sebanyak 19 orang siswa. Pada siklus pertama pada tabel 1.1 terlihat sudah ada peningkatan secara klasikal yang tuntas $\geq 75$ sekitar $73.33 \%$ yaitu 22 orang siswa. Pada siklus ke-2 juga terus meningkat sehingg tercapai ketuntasan pemahaman konsep secara klasikal sesuai dari kriteria ketuntusan yaitu sekitar $83.33 \%$ yaitu 25 orang siswa yang tuntas dari 30 orang siswa.Hal tersebut berarti penelitian tindakan kelas nya telah selesai pada siklus 2 .

\section{Pembahasan Pra tindakan, Siklus 1, dan Siklus 2}

Pembelajaran pra tindakan ini dilaksanakan sebanyak satu kali pertemuan ( 2 x 45 menit) pada pokok bahasan pembagian bilangan. Pelaksanaan pembelajaran dilakukan dengan menerapkan pembelajaran ceramah disertai penugasan. Selanjutkan ketika mulai menerapkan Model Pembelajaran Langsung, peneliti ternyata membutuhkan 2 siklus untuk meningkatkan hasil belajar siswa.

Pada siklus pertama, peneliti atau guru melakukan mulai tahap perencanaan sampai tahap refleksi. Pada siklus 1 ini secara klasikal ketuntasan hasil belajar sudah sampai $73.33 \%$ yaitu 22 orang siswa, namun belum memenuhi standar yang telah ditetapkan sebelumnya. Maka oleh sebab itu guru melakukan refleksi hasil dari observasi yang telah dilakukan oleh observer. Dari hasil pengamatan, bisa dilihat keaktifan siswa sudah mulai tampak dalam mengikuti pembelajaran. Hal ini dapat dilihat dari keseriusan siswa dalam memperhatikan guru dan menerima intruksi yang diberikan guru dengan menggunakan alat oeraga yang telah dipersiapkan oleh guru sebelumnya sebagai alat bantu.Peran guru membimbing siswa juga sangat memberi respon yang baik bagi siswa. Sebagian siswa sudah mulai terbiasa dalam melaksanakan proses pembelajaran model Pembelajaran langsung. Untuk itu peneliti sebagai guru akan melakukan perbaikan yaitu pada pertemuan selanjutnya guru akan lebih memaksimalkan alat peraga yang diberikan dan fokus membimbing siswa agar bisa belajar tuntas. Dan pada kegiatan akhir, guru mempersingkat waktu untuk menyimpulkan dan lebih menambahkan waktu untuk mengerjakan soal quiz.

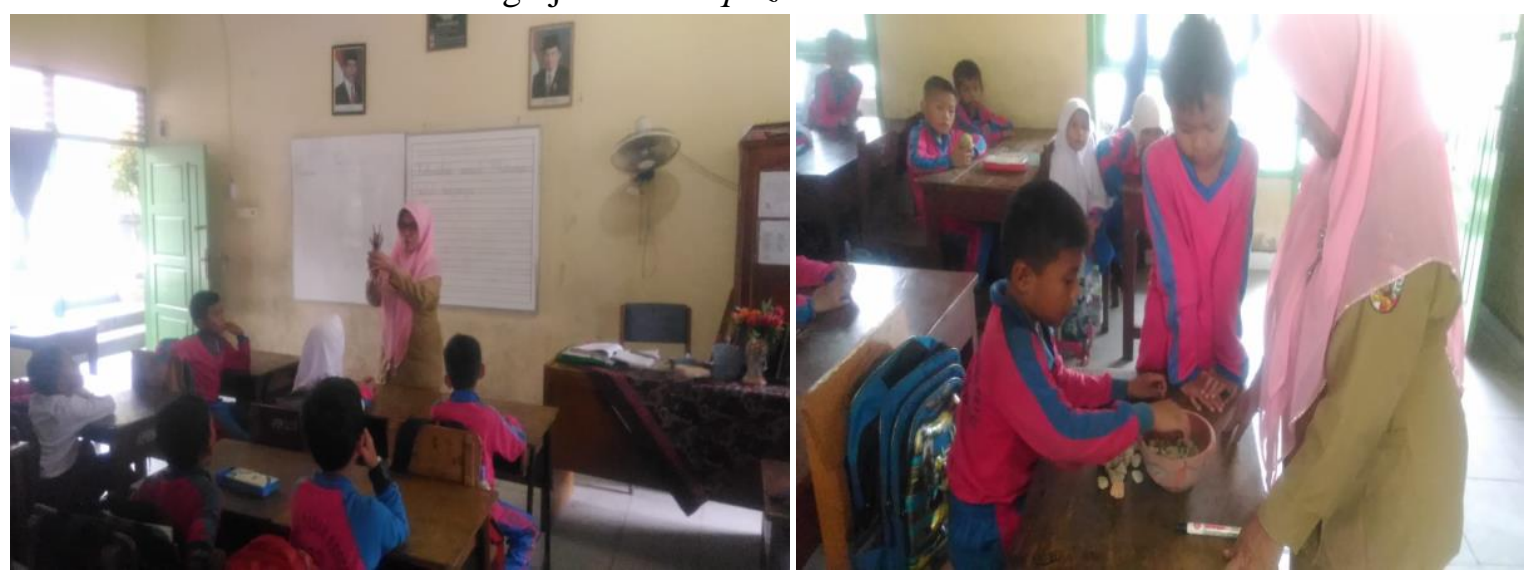




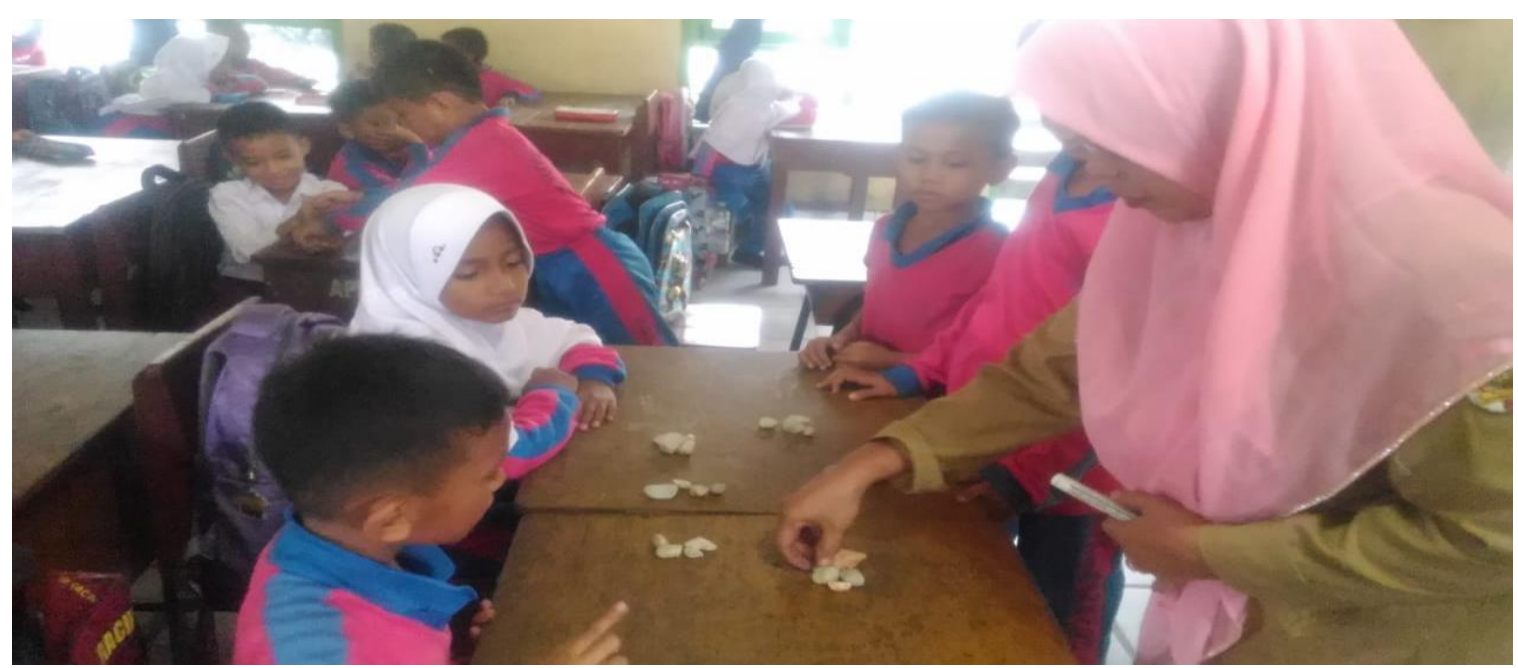

Gambar 1.2 Proses Pembelajaran Model Pembelajaran Langsung Siklus 1

Pada siklus kedua, peneliti sudah memperbaiki berdasarkan hasil refleksi pada siklus pertama. Siswa sudah mulai aktif mengikuti proses pembelajaran dengan model pembelajaran langsung.
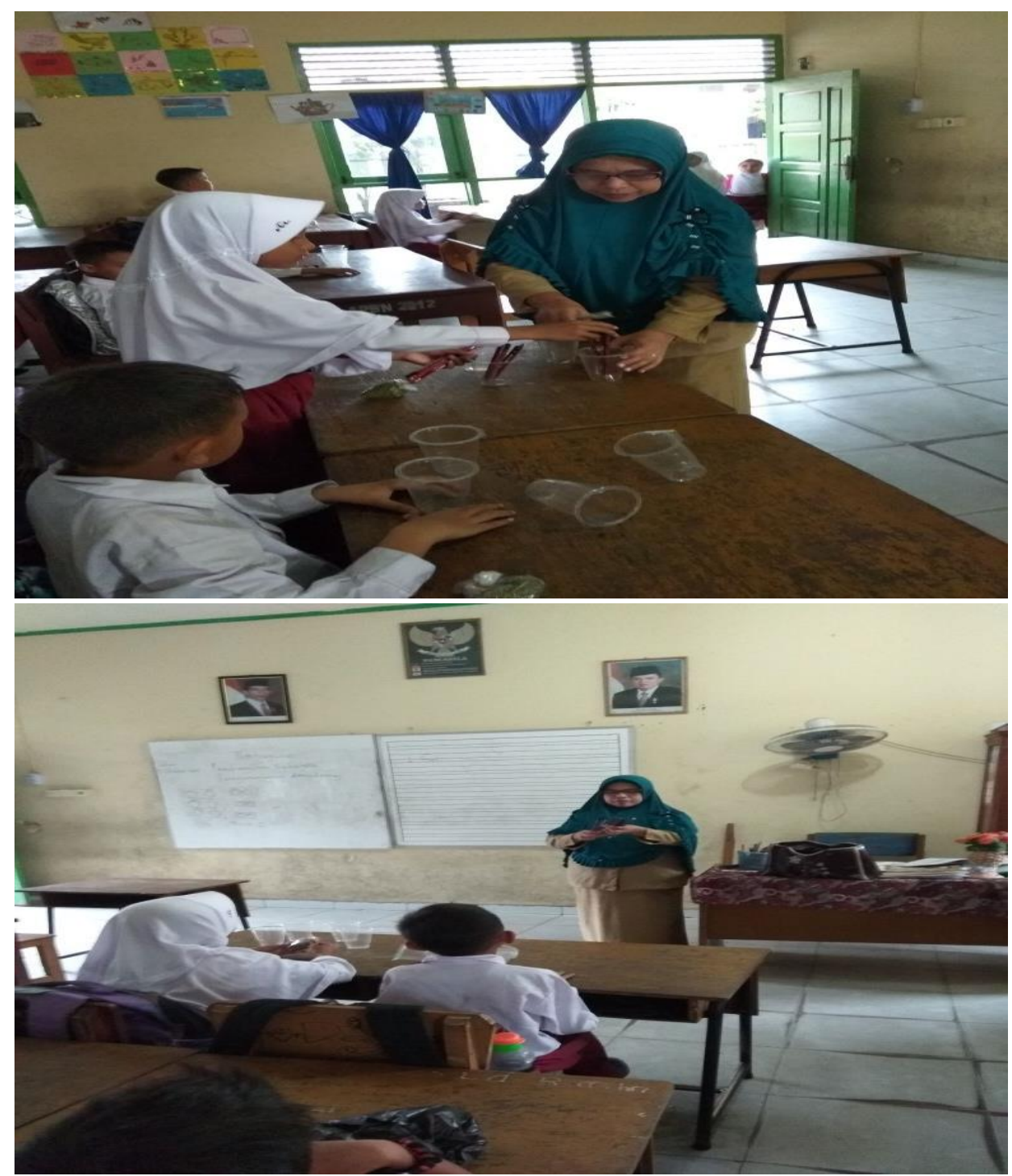


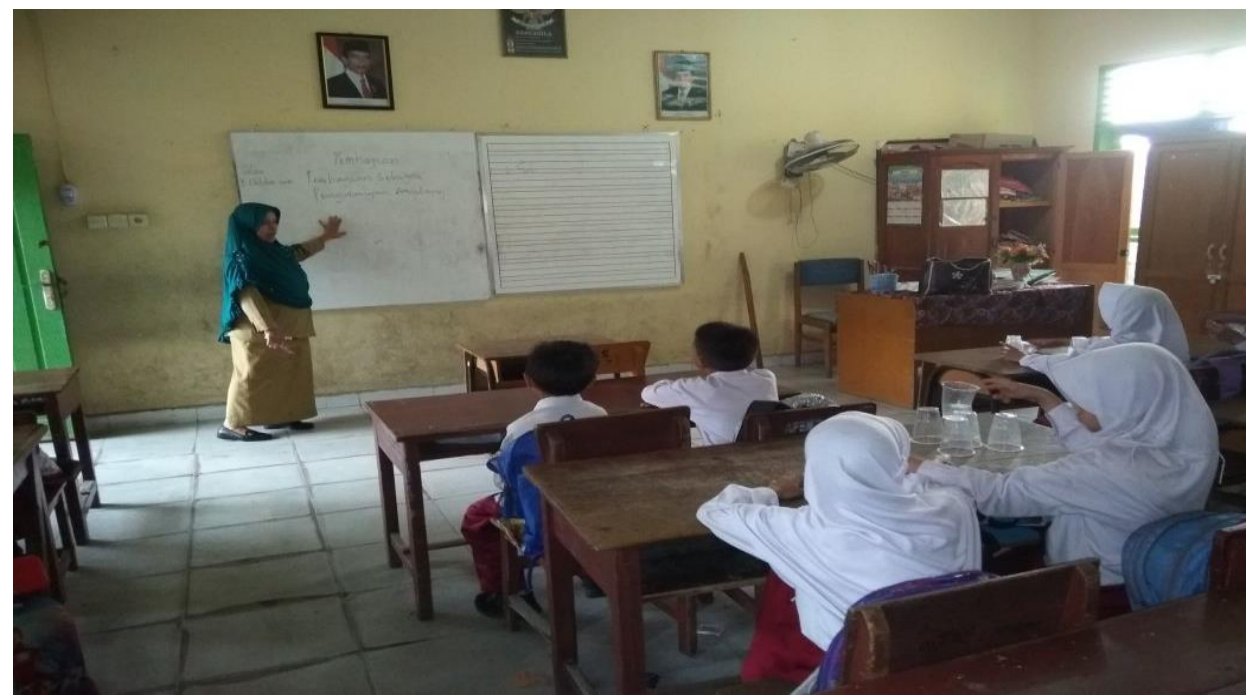

Gambar 1.3. Proses Pembelajaran model Pembelajaran Langsung Siklus 2

Pada gambar 1.3 terlihat bahwa Keaktifan siswa dalam belajar sudah memuaskan, ditandai dengan adanya kesungguhan siswa dalam proses pembelajaran. siswa sudah lebih aktif dalam proses pembelajaran, siswa mendengarkan intruksi dari guru dan mengerjakan. Selain itu siswa berani mempresentasikan hasil kerjaan yang mereka kerjakan, dan siswa/kelompok lain mau bertanya apabila ada yang tidak mereka mengerti.Dari data tes hasil belajar pemahaman konsep yang diadakan pada siklus 2 terjadi peningkatan dari sebelumnya. Hal ini juga dapat diihat dari lembar jawaban siswa berikut ini:

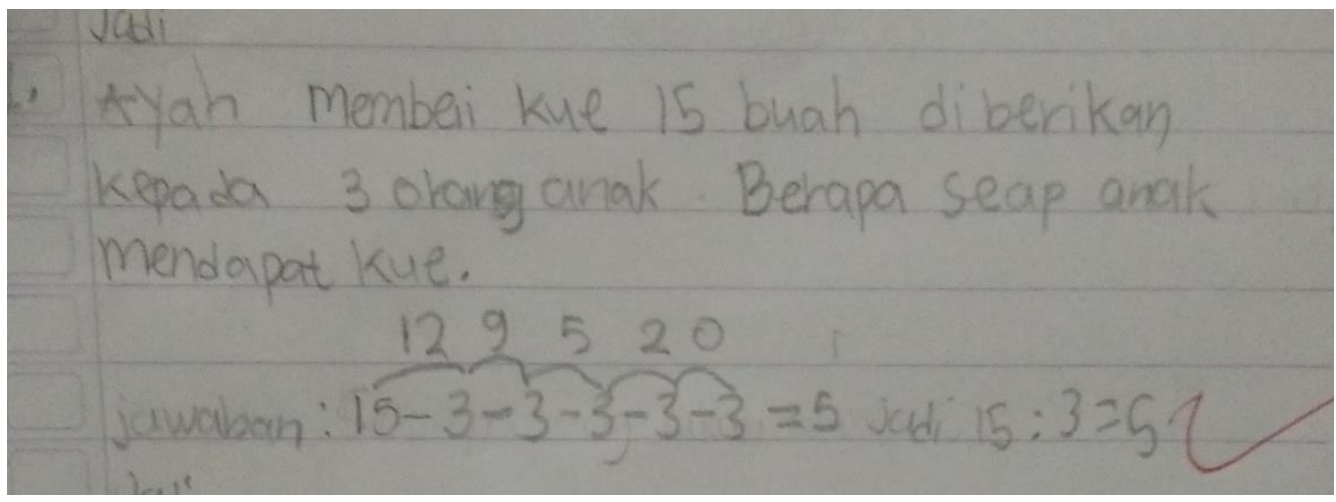




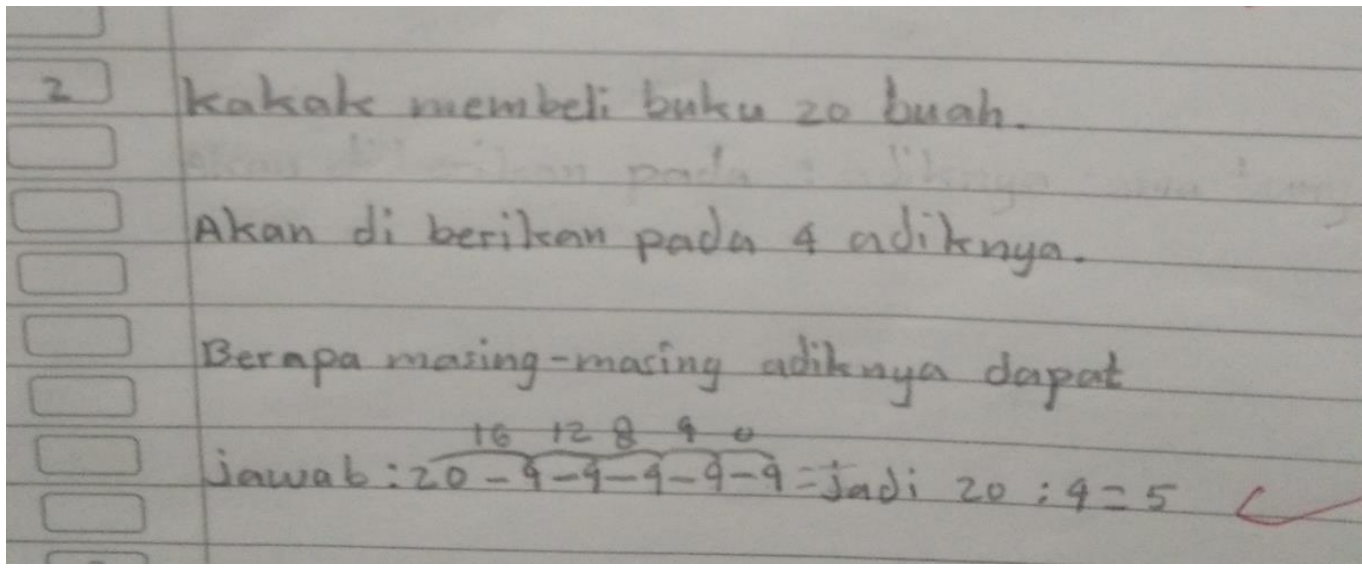

Gambar 1.4.Lembar Jawaban Siswa

Pada gamabr 1.4 terlihat bahwa siswa sudah dapat memahami konsep pembagian yaitu pengurangan berulang. Siswa sudah dapat menyelesaikan soal cerita tersebut dengan memahami konsep yang telah mereka pelajari.

\section{KESIMPULAN}

Berdasarkan hasil dari siklus 1 dan siklus 2 yang telah dilakukan peneliti, maka dapat diambil kesimpulan dengan menerapkan model Pembelajaran Langsung (Direct Learning) hasil belajar berupa pemahaman konsep siswa terus meningkatkan, dan pada siklus kedua sudah mencapai target yang di inginkan guru secara klasikal yaitu sekitar $83.33 \%$ siswa sudah mencapai nilai $\geq 75$.

\section{DAFTAR PUSTAKA}

Arikunto,S. 2006. Prosedur Penelitian Suatu Pendekatan Praktek.Jakarta: Rineka Cipta.

BSNP. 2006. Permendiknas RI No. 22 Tahun 2006 tentang Standar Isi untuk. Satuan Pendidikan Dasar dan Menengah. Jakarta.

Paul Eggen dan Don Kauchak, terj Satrio Wahono, 2012, Startegi dan Model Pembelajara, Jakarta: Permata Puri Media.

Silberman, Melvin L. 2006. Active Learning 101 Cara Bealajar Siswa Aktif. Bandung: Nuansa.

Sudjana, Nana. 2010. Penilaian Hasil Proses Belajar Mengajar.Cet XV. Bandung:Ramaja Rosdakarya 